\title{
Employment and Development as Poll Issues in Bihar: A Paradigm Shift in Electioneering
}

\author{
Srirang K Jha* and Amiya Kumar Mohapatra ${ }^{* *}$
}

\begin{abstract}
Bihar poll has always been characterized by caste coalitions. The political parties generally give poll tickets to the candidates belonging to the most dominant caste in terms of number in any constituency. All the socio-economic issues take a backseat during polls in Bihar, which is one of the most backward states of the country. It is true that all the political parties bring out nicely worded manifestos during each election. But such manifestos are just an appendage to the caste-based poll strategies adopted by all the political parties without any exception. The caste calculations are so well ingrained across the party lines that newspapers unusually publish the percentage break up of poll candidates with their castes. This article explores how the scenario has changed during the elections in 2020 when every political party is focusing on employment and development. Indeed, the caste coalitions have taken a backseat. It would be worthwhile to see whether the issue of employment and development actually influences the election results or people stick to a more conservative approach to voting based on caste affiliations while they continue to suffer due to joblessness and poverty as well as lack of basic amenities like health care, education, roads, power supply, potable water, etc.
\end{abstract}

KEYWORDS: Employment, Development, Election, Bihar, India

\section{INTRODUCTION}

Bihar poll has always been characterized by caste coalitions. The political parties generally give poll tickets to the candidates belonging to the most dominant caste in terms of number in any constituency. All the socio-economic issues take a backseat during polls in Bihar, which is one of the most backward states of the country. It is true that all the political parties bring out nicely worded manifestos during each election. But such manifestos are just an appendage to the caste-based poll

\footnotetext{
*Associate Professor and Head, General Management Area, Apeejay School of Management, New Delhi, India E-mail: jha.srirang@gmail.com

*** Deputy Director, FOSTIIMA Business School, New Delhi, India

E-mail:amiyaeco125@gmail.com
} 


\section{Journal of Politics \& Governance, Vol. 8, No. 10, October 2020}

strategies adopted by all the political parties without any exception. The caste calculations are so well ingrained across the party lines that newspapers unusually publish the percentage break up of poll candidates with their castes. It is presumed that the caste-based distribution of poll tickets would motivate the voters of the particular caste to vote for the political party which has fielded maximum number of candidates from their community. The caste-based poll strategies have worked for over last 70 years. Chirag Paswan, President Lok Janshakti Party, has been aptly quoted as saying 'Governments have either been formed or fallen only through smart social engineering of castes' (Singh, 2020).

\section{PARADIGM SHIFT}

The Bihar polls in 2020 have turned a bit different. All the political parties are now focusing on development and employment. The poll strategists are apprehensive that the poll results might not remain the function of caste coalitions this time around. Hence, the leaders of all the major political formations in Bihar are promising jobs or job opportunities and a holistic ecosystem for overall development of the state. For a change, the political tacticians feel that this time people would vote for employment and development rather than hitherto popular and time-tested caste coalitions. Indeed, people are now fed up with caste-based politics which has constantly failed to provide them with basic amenities like primary, education, primary healthcare, roads, bridges, electricity, potable water, etc. This phenomenon is evident from the high incidence of anti-incumbency sentiments among people of Bihar as reflected in their constant rebuttal during the visits of ministers and legislators in their villages. On several occasions, the ministers and legislators have returned without entering the villages in their respective constituencies. Social media has several videos showing the disgruntled villagers asking difficult questions to the ministers and legislators who have invariably failed to keep their promises during the last five years.

Taking cues from the public sentiments in Bihar, the opposition in the state has come forward to engineer a change of guard through populist measures as filling the vacancies and creating new government jobs, unemployment allowance and promoting an ecosystem conducive for overall development and prosperity. The political formation popularly known as the Grand Alliance led by Rashtriya Janata Dal (RJD) has announced filling all the 4.5 lakh vacant positions in the state government and creates 5.5 lakh fresh jobs under the state government if voted to power besides changing the salary structure of the contractual teachers at par with that of the permanent teachers (Press Trust of India, 2020a). Congress which is a prominent ally in the Grand Alliance has promised unemployment allowance to tune of INR 1500 per person without any job in addition to augmenting the income of the traditional handicrafts worker involved in making of Sujni, Madhubani, Khatwa etc. (Press Trust of India, 2020b, Times Now Digital, 2020).

Even the Lok Janshakti Party has promised filling all vacant positions in Bihar, equal pay to equal work for all government employees working on contract, starting a film city and a coaching city and college of education in each district of the state (Singh, 2020). These measures are likely to create jobs in the state and streamline education system. Large number of students from Bihar has to go to Kota in Rajasthan for coaching of engineering and medical entrance examinations. If one of the cities of Bihar is developed as a coaching hub, it would not only amplify the success rate of students of Bihar in IITJEE and NEET but also create thousands of jobs in the allied areas like paying guest accommodation, rental income from houses and other commercial facilities, etc. Plural, which is a 


\section{Journal of Politics \& Governance, Vol. 8, No. 10, October 2020}

relatively new political party contesting on all the seats in Bihar, has also charted its plan for overall development of the state with a lofty promise of 80 lakh jobs (India TV, 2020).

The incumbent government under National Democratic Alliance (NDA) is under tremendous pressure from the job promises made by the opposition parties. According to C-Voter-ABP News opinion poll, $52 \%$ respondents have indicated that unemployment is an election issue this time (ABP News Bureau, 2020). Hence there has been sharp reaction from both Janata Dal United (JDU) and Bhartiya Janata Party (BJP) at the state level regarding bizarre nature of job promises and impossibility of fulfilling those assurances owing to the lack of resource available in the state treasuries. However, looking at the traction of the crowd towards RJD, the main opposition in Bihar, the central leadership of BJP was forced to make counter promise of 19 Lakh job opportunities over a period of next five years, much to the discomfiture of their state leaders. However, the job promises of the BJP appear to be an afterthought and only time will tell whether people really pay any heed to such promises. Even if the GDP of Bihar has increased from $3 \%$ to $11.3 \%$ in last 15 years of the rule of NDA (Hindustan Times, 2020), the socio-economic conditions of people in Bihar continues to be deplorable. The quality of life and livelihood have not improved in Bihar although real growth rate of the state has been 10.52\% from 2004-05 to 2014-15 (Ganguli and Bakshi, 2020). On all the major parameters of development, Bihar usually comes last. Hence, it will be difficult for the voters in Bihar to trust what the BJP promises in spite of enviable real growth rate.

\section{CRITIQUE}

High incidence of unemployment and lack of development as reflected in deplorable civic amenities in Bihar have emerged as key poll issues in the state. Unemployment rate in Bihar is $10.2 \%$ as against 5.8\% for all India as per the Periodic Labour Force Survey 2018-19 (Jha and Kishore, 2020). In September 2020 , the unemployment rate was $11.9 \%$ as against the national average of $7.4 \%$ as per the survey conducted by Centre for Monitoring Indian Economy (Dutta, 2020). In 2004-05, Bihar's unemployment rate was 0.8 times the all-India unemployment rate which has increased over the years (Jha and Kishore, 2020). Only 10\% of the jobs in Bihar are salaried jobs (Jha and Kishore, 2020), thus majority of the people are either engaged in farm sector or informal sector low paying jobs. Jha and Kishore (2020) rightly observe:

"Bihar fares worse than the all-India average when it comes to the share of workers who have a regular job. According to the 2018-19, PLFS, $23.8 \%$ of India's workers had a salaried job. This number was just $10.4 \%$ for Bihar. The share of workers with a salaried job has increased from 4.2\% in 2004-05 EUS, which corresponds with the period when Nitish Kumar took over the chief minister of the state. However, the points remains that it is still significantly worse than the allIndia situation."

Furthermore, the issue of unemployment is not limited to particular caste. Even those who have been traditional supporters of NDA are facing the heat, especially in the wake of Covid-19. Hence, unemployment has turned out to be a major poll issue in Bihar. However, the incumbent NDA functionaries are apparently complacent, totally unmindful of their failures to deliver good governance and improve the quality of life of people in Bihar. Their narrative of development fails miserably on the ground. 


\section{Journal of Politics \& Governance, Vol. 8, No. 10, October 2020}

\section{CONCLUSION}

Outcomes of Bihar election in 2020 are likely to be quite interesting. Large numbers of people have returned to their native villages in the wake of Covid-19. They have seen the prosperity as well as adversity. Hence the voter turnout will also be higher this time around and might influence the actual results of the elections. However, it will be intriguing to watch whether high incidence of joblessness, poor working conditions of contractual workers, lack of suitable job opportunities, corruption at government offices at block and district level, pathetic government services, poor healthcare infrastructure and facilities and lacklustre education system override the caste factor and actually surprise the pollsters.

\section{REFERENCES}

ABP News Bureau. (2020). Bihar elections ABP-CVoter opinion poll live: JDU-BJP gets majority in 170 seats of 4 regions. ABP News, 24 October 2020. Accessed from https://news.abplive.com/news/india/bihar-election-opinion-poll-live-updates-abp-cvoteropinion-poll-who-will-win-bihar-assembly-elections-seatwise-opinion-poll-results-1372139

Dutta, P. K. (2020). Naukri dot kaun in Bihar as BJP promises 19 lakh jobs to Tejashwi's 10 lakh. India Today, 22 October 2020. Accessed from https://www.indiatoday.in/elections/bihar-assembly-polls-2020/story/biharassembly-election-manifesto-employment-promises-1734077-2020-10-22

Ganguli, B. and Bakshi, A. K. S. (2020). Progressiveness of Finance Commission: A critical review of Bihar. Economic \& Political Weekly, 55 (43). Accessed from https://www.epw.in/journal/2020/43/special-articles/progressiveness-finance-commission.html

India TV. (2020). Pushpam Priya Choudhary promises 80 lakh jobs, lift prohibition in manifesto for Bihar election. India TV, 20 October 2020. Accessed fromhttps://www.indiatvnews.com/elections/news-priya-choudhary-plurals-pushpampromises- 80-lakh-jobs-releases-manifesto-for-bihar-assembly-election-2020-658478

Jha, A. and Kishore, R. (2020). Why is everyone promising jobs in Bihar elections? Hindustan Times, 23 October 2020. Accessed from https://www.hindustantimes.com/india- news/why-iseveryone-promising-jobs-in-bihar-elections/story- PakeHDedmBrT36EG7xRkKP.html

Press Trust of India. (2020a). Grand Alliance promises jobs to youths, end farm laws in Bihar if voted to power. The Economic Times, 17 October 2020. Accessed from https://economictimes.indiatimes.com/news/elections/assembly-elections/bihar/grand-alliancepromises-jobs-to-youthsend-farm-laws-in-bihar-if-voted-to- power/articleshow/78718718.cms

Press Trust of India. (2020b). Bihar polls: Congress manifesto promises $10 \mathrm{~L}$ jobs, farm loan waiver, Rs 1,500 unemployment allowance. Deccan Herald, 21 October 2020. Accessed from https://www.deccanherald.com/election-2020/bihar-polls-congress-manifesto-promises- 10 ljobs-farm-loan-waiver-rs-1500-unemployment-allowance-905162.html

Singh, S. (2020). Bihar elections: LJP manifesto - Jobs, 'caste-free' society. The Indian Express, 22 October 2020. Accessed from https://indianexpress.com/elections/bihar-elections- ljpmanifesto-jobs-caste-free-society-6827760/

Times Now Digital. (2020). Loan waivers, regulations to reject farm laws in Congress' 'Badlav Patr' for Bihar Assembly elections 2020. Times Now, 21 October 2020. Accessed from https://www.timesnownews.com/india/bihar/article/bihar-assembly-elections-congressreleases-manifesto-for-upcoming-polls/670529 